The species may be known as CRAspedaCUsta SOWERBII, nov. gen. et sp.-I name the species in honour of $\mathrm{Mr}$. Sowerby, who discovered it, and to whose quick observation and courteous kindness zoologists are indebted for the knowledge of this interesting animal.

The sole character which I can give as specific over and above the generic characters summarised above is that of size. The diameter of the disk does not exceed one-third of an inch.

Locality.-The water-lily tank in the gardens of the Botanical Society, Regent's Park, London.

Very abundant during June, i880. Probably introduced from the West Indies.

E. RAY LANKESTER

\section{NOTES FROM FAVA}

$\mathrm{T}$

$\mathrm{HE}$ following extracts from a letter written from Java by Mr. Henry O. Forbes to Mr. H. N. Moseley, F.R.S., have been sent to us for publication as of consi-
derable interest. The letter is dated March I9. Mr. Forbes, who has been engaged in collecting in Java, expects shortly to leave for Celebes, Timor, Timor-laut, and other eastern islands. Timor-laut is the most important island of the Malay Archipelago yet remaining to be explored, and is likely to yield many natural history treasures. Mr. Forbes's letter refers to certain passages in Mr. Moseley's "Notes by a Naturalist on the Challenger." The question of the mode of growth of Myrmecodia and Hydrophytum has been lately before the Linnean Society.

"With regard to birds carrying seeds from one island to another, I have observed on the Cocos Keeling Islands (South Indian Ocean) a species of heron which nested in a high tree (species unknown) there, quite covered with its oblong hooked seeds. I was informed by the proprietor of the island that many of these birds, from their feathers getting so thickly covered with the seeds, actually die. I can therefore imagine that many of these seeds might adhere for even weeks and months, and so get transported to very distant regions.

"At p. 493 you note the habit of hot-water drinking. It is quite a custom among, at any rate, the Sudanese, among whom I have been living some time, who, in the afternoons, invite each other to come and have a cup of hot water. It is drunk either plain or with a little arenga sugar.

"I have found here a large quantity of algæ growing in the hot springs at a temperature of $132^{\circ} \mathrm{F}$. What the species are or is I have not yet ascertained.

"With reference to Myrmecodia and Hydnophytum, I find some difficulty in reconciling in all cases the statement (p. 389) that 'the ants gnaw at the base of the stem, and the irritation produced causes the stem to swell,' with what I have myself observed. I have grown many young seedlings, some of which were entirely unmolested by ants, and yet produced a bulbous swelling at the base; others were certainly scratched, but that was all, by the ants, the smallest scar being visible. On opening many of those which were unmolested I observed a degenerated, soft, spongy portion, not in connection with the exterior. May not this spot increase till an external opening is formed, and the ants have an entrance made for them to carry out, as I have seen them doing, the soft spongy substance inside? I have seen other secdlings that had a small orifice close to the rootlet, leading into an interior oval or round expansion in the bulb, and though I closely observed them I failed to detect ants touching them. All these seedlings I grew from the seed till they reached at most a couple or three inches or a little more, when they generally became the home of some ants. After they had become infeste 1 I did not pursue observations on them, as my time was much occupied, and because the object of my observation was to discover if they bulbed, \&c., without the aid of ants. I should much like to see these plants grow with all ant life removed from them entirely. If opportunity again offers I shall continue my experiments. I have repeatedly noticed on large Myrmecodia and Hydnophyta which were crowded with ants (on both genera I have found only one species of ant) that in many places irregularlyshaped areas of degeneration existed quite cut off from communication with the wonderful series of galleries and chambers which form this ant-hive. These were found oftenest near the upper portion of the bulb, and towards which excavations were being directed. I have not. observed that the surface of the rounded mass gives off any twigs bearing leaves or flowers. All my specimens have had the shape of a bulb more or less gobose, or elongate, prickly, tenanted by ants, giving origin to a much thinner stem, not, or rarely, chambered nor passaged, but also armed, and from which the leaves and sessile flowers proceeded, the latter from hollows in which numerous ants were constantly moving about. The Hydnophyta generally give off at once leaves at the summit of a more or less irregular bulb.

"I have seen the same species of ant inhabiting the swollen-up hollow leaves of a species of Hoya or Eschynanthus. The plant I saw had many of its leaves in this condition. I gathered it one day while on the march, and I fear it is lost. It may have been sent to the British Museum, but I am not certain. I have not met with another instance. There was a small hole in the apex of the lcaf, and through it the ants came and went. The leaf looked as if all the mesophyllum had been cleared out and the epidermis blown out into a bladder. This observation may not be quite accurate as to the description of leaf, but I noted that the species of ant was the same.

"Here it is quite impossible to obtain a perfect rhinoceros skull, unless one has the good fortune to shoot it oneself, for the horn is so highly prized that it alone fetches from 200 to 300 rupees (Dutch guelders), being eagerly bought by the Chinese. It is believed in by all the natives as a sure and certain antidote for snake-bites and for purifying water. A respectable hadji affirmed to me with the persistency of belief that on his way to Mecca -he went in a native vessel-the stock of fresh water on board ran out, and that all on the vessel, by drinking sea-water out of a rhinoceros horn, found it to be--not salt water!"

\section{ON THE FERTILISATION OF COBAEA PENDULIFLORA (HOOK. FIL.)}

COBAEA PENDULIFLORA is a graceful climber, growing rather sparingly in our mountain-forests. It was described and figured by Karsten under the name of Rosenbergia penduliflora ("Flora.Columbix," I. 27, t. ix.), and afterwards in the Bot. Mag., i. 5757. Karsten's plate is very pretty, but in all the specimens $I$ have seen the linear lobes of the corolla were never so red as he paints them, nor do the stamens ever hang straight downwards parallel to the style, as his figure shows. The plate in the Botanical Magazine has only one defect, the artist having overlooked the hooklets and the ends of the tendrils.

The plant grows exceedingly quickly when kept in shade. A specimen now in my garden was raised from seed sown October 3, 1879, which sprang up a fortnight later, and covered, in less than three months, a wall twelve feet high and ten feet long. It climbs exactly in the same manner as Cobaea scandens, described by Darwin in his "Climbing Plants." The flowers have very little to attract attention, their colour being dull green, with very little red on the filaments, and there is no smell. Though not of great horticultural interest, the plant fully deserves the attention of the botanist on account of the peculiar circumstances under which the flowers are fertilised. Sir J. D. Hooker has made already some pertinent remarks on 